\title{
Keong Mangrove Cassidula angulifera (Gastropoda: Ellobiidae) di Pantai Payum Merauke Papua Indonesia: Struktur Populasi, Karakteristik Lingkungan dan Faktor Penentu Distribusi serta Kepadatannya (Mangrove Snail Cassidula angulifera (Gastropod: Ellobiidae) at Payum Merauke Beach Papua Indonesia: Population Structure, Environmental Characteristics and Determining Factors for Distribution and Density)
}

\author{
Syahrial $^{1^{*}}$, Dandi Saleky ${ }^{2}, \&$ Sendy L. Merly ${ }^{2}$ \\ ${ }^{1}$ Program Studi Ilmu Kelautan, Fakultas Pertanian, Universitas Malikussaleh Aceh Utara \\ ${ }^{2}$ Jurusan Manajemen Sumberdaya Perairan, Fakultas Pertanian, Universitas Musamus, Merauke Papua
}

*E-mail: syahrial.marine@unimal.ac.id

Memasukkan: Januari 2021, Diterima: Februari 2021.

\begin{abstract}
Coastal ecosystems have high biodiversity, where Indonesia is one of the countries with the highest diversity of marine organisms in the world, so the study of mangrove snails Cassidula angulifera (Gastropoda: Ellobiidae) has been conducted in September 2020 on the beach Payum Merauke Regency Papua Province with the aim as a basic data in mangrove management in Indonesia, especially in Merauke Regency which is reviewed from population structure, environmental characteristics and determining factors of distribution and density of mangrove snail $C$. angulifera. Data of mangrove conch $C$. angulifera and mangrove forest Payum Merauke beach collected by making transect lines and plots drawn from the reference point (outer mangrove stand) and perpendicular to the shoreline to the mainland. Furthermore, to find out the environmental and factors that determine the distribution and density of mangrove snails $C$. angulifera on the beach Payum Merauke Regency of Papua Province analyzed using PCA. The results showed that for the population structure, the highest density of mangrove snail C. angulifera is at Station $2\left(40.67 \mathrm{ind} / \mathrm{m}^{2}\right)$, while the lowest is at Station 3 (5 ind/ $\mathrm{m}^{2}$ ), then the distribution pattern is classified as uniform $(\mathrm{I} \delta<1)$. For environmental characteristics of mangrove snail $C$. angulifera on the beach Payum Merauke Regency of Papua Province shows that the density of mangroves is classified as high ( $>1000 \mathrm{ind} / \mathrm{ha}$ ), the water temperature ranges from $28.33-31.67^{\circ} \mathrm{C}$, DO $5.60-7.67 \mathrm{mg} / \mathrm{L}, \mathrm{pH} 6.83-7.53$, salinity $29.33-30.00 \%$, and form two groups. As for the determining factor of distribution and density of mangrove snails $C$. angulifera on the beach Payum Merauke Regency of Papua Province is influenced by water temperature, DO, and mangrove density.
\end{abstract}

Keywords: snail, gastropod, mangrove, Cassidula angulifera, Payum beach, Merauke

\begin{abstract}
ABSTRAK
Ekosistem pesisir memiliki keanekaragaman hayati yang tinggi, dimana Indonesia merupakan salah satu negara dengan keragaman organisme laut tertinggi di dunia, sehingga kajian keong mangrove Cassidula angulifera (Gastropoda: Ellobiidae) telah dilakukan pada bulan September 2020 di pantai Payum Kabupaten Merauke Provinsi Papua dengan tujuan sebagai data dasar dalam pengelolaan mangrove di Indonesia khususnya di Kabupaten Merauke yang ditinjau dari struktur populasi, karakteristik lingkungan maupun faktor penentu distribusi dan kepadatan keong mangrove $C$. angulifera. Data keong mangrove $C$. angulifera dan hutan mangrove pantai Payum Merauke dikumpulkan dengan membuat transek garis dan plot yang ditarik dari titik acuan (tegakan mangrove terluar) dan tegak lurus garis pantai sampai ke daratan. Selanjutnya, untuk mengetahui penciri lingkungan dan faktor yang menentukan distribusi maupun kepadatan keong mangrove $C$. angulifera di pantai Payum Kabupaten Merauke Provinsi Papua dianalisis menggunakan PCA. Hasil kajian memperlihatkan bahwa untuk struktur populasinya, kepadatan keong mangrove C. angulifera tertinggi berada pada Stasiun $2\left(40,67 \mathrm{ind} / \mathrm{m}^{2}\right)$, sedangkan terendahnya berada pada Stasiun $3\left(5 \mathrm{ind} / \mathrm{m}^{2}\right)$ dengan pola penyebarannya tergolong seragam $(\mathrm{I} \delta<1)$. Selanjutnya, untuk karakteristik lingkungan keong mangrove $C$. angulifera di pantai Payum Kabupaten Merauke Provinsi Papua memperlihatkan bahwa kerapatan mangrovenya tergolong tinggi $(>1000 \mathrm{ind} / \mathrm{ha})$, suhu perairan berkisar antara 28,33 $-31,67^{\circ} \mathrm{C}, \mathrm{DO} 5,60-7,67$ $\mathrm{mg} / \mathrm{L}$, pH 6,83 - 7,53, salinitas 29,33 - 30,00\% dengan penciri lingkungannya membentuk 2 kelompok. Sementara untuk faktor penentu distribusi maupun kepadatan keong mangrove $C$. angulifera di pantai Payum Kabupaten Merauke Provinsi Papua dipengaruhi oleh suhu perairan, DO dan kerapatan mangrove.
\end{abstract}

Kata Kunci: keong, gastropoda, mangrove, Cassidula angulifera, pantai Payum, Merauke 


\section{PENDAHULUAN}

Mangrove menyediakan berbagai layanan ekosistem (Barbier et al. 2011; Lee et al. 2014), dimana fungsi mangrove yang terpenting adalah sebagai daerah penghubung antara daratan dan lautan (Purnobasuki 2011), sedangkan secara umumnya, mangrove berfungsi sebagai daerah nursery ground, spawning ground dan feeding ground bagi semua biota yang berasosiasi di dalamnya (Schaduw 2019). Selain itu, fungsi mangrove juga dikelompokkan menjadi tiga kategori yaitu secara fisik, biologi dan sosial ekonomi (Eddy et al. 2015). Untuk secara fisiknya, mangrove berfungsi sebagai pertahanan adaptif yang dapat mengimbangi kenaikan permukaan air laut (Krauss et al. 2014), mengurangi gelombang laut maupun badai serta sebagai garis pertahanan pertama dalam melawan banjir dan erosi (Menendez et al. 2020), menjebak benda-benda yang diangkut oleh arus laut yang mengambang (seperti benda plastik) (Martin et al. 2019) hingga sebagai penahan lumpur serta perangkap sedimen yang diangkut oleh aliran air permukaan dan pencegah intrusi air laut ke daratan (Lasibani \& Kamal 2010). Sementara secara biologinya, mangrove berfungsi sebagai penyimpan karbon (Murdiyarso et al. 2015; Kelleway et al. 2016), penyedia layanan untuk perikanan (Benzeev et al. 2017; Goecke \& Carstenn 2017), produksi pakan untuk ikan (Murdiyarso et al. 2015) hingga pemurnian air (Feagin et al. 2010). Selanjutnya untuk sosial ekonomi, mangrove berfungsi sebagai penghasil kayu (Lasibani \& Kamal 2010; Murdiyarso et al. 2015), penunjang jasa ekosistem bagi pariwisata (Costanza et al. 2014), daerah penangkapan perikanan (Lasibani \& Kamal 2010) serta sebagai penyedia makanan, minuman dan obat-obatan (Alongi 2002; Lasibani \& Kamal 2010).

Terlepas dari hal di atas, mangrove merupakan spesies tumbuhan yang mendominasi di lahan basah pesisir pada daerah tropis dan meluas ke garis lintang yang lebih tinggi serta meningkatkan jangkauannya ke batas kisaran kutub (Saintilan et al. 2014), dimana mangrove mampu mentolerir kadar garam air laut (Wang et al. 2020) serta mampu tumbuh berkembang di substrat yang bersifat asam dan anoksik (Reid et al. 2010) dengan biodiversitasnya terdiri dari 84 spesies secara global yang tergolong ke dalam 24 genus dan 16 famili. Tujuh puluh (70) spesies dengan 16 genus dan 11 famili merupakan mangrove sejati, sedangkan 14 spesies dengan 8 genus dan 5 famili termasuk mangrove ikutan (Wu et al. 2008). Namun, saat ini hutan mangrove telah mengalami kerusakan/ kehilangan yang sangat besar/tinggi (Menendez et al. 2020) yaitu menurun dari $139.777 \mathrm{~km}^{2}$ pada tahun 2000 menjadi $131.931 \mathrm{~km}^{2}$ pada tahun 2014 (Hamilton \& Casey 2016), sehingga laju deforestasi hutan mangrove lebih tinggi daripada hutan global (Giri et al. 2007; FAO 2007) dan mangrove yang tersisa akibat degradasi, bisa menjadi fungsional yang paling berharga pada abad ke-21 nanti (Duke et al. 2007; Polidoro et al. 2010).

Menurut Ariyanto et al. (2018) keong mangrove Cassidula angulifera merupakan salah satu kelompok gastropoda primitif yang mendominasi di daerah tropis, dimana secara ekologis dan fisiologisnya, $C$. angulifera dapat hidup di daerah transisi antara laut dan darat serta mampu bertahan terhadap perubahan lingkungan (Bremner 2008). Pada ekositem mangrove, keong mangrove $C$. angulifera mempunyai keterkaitan yang kuat dengan tegakan mangrove Rhizophora stylosa, kemudian keong mangrove $C$. angulifera yang berukuran besar lebih menyukai substrat yang bertipe lempung daripada pasir, sedangkan yang berukuran kecil dan sedang lebih menyukai substrat bertipe pasir daripada lempung (Ariyanto et al. 2018). Selanjutnya, keong mangrove $C$. angulifera memiliki nama sinonim Auricula angulifera (Petit de la Saussaye, 1841) (Adams \& Adams 1854; WoRMS 2021) dan A. subrepta (Hombron \& Jacquinot, 1848) (WoRMS 2021) dengan ukuran cangkangnya berkisar antara 25 - $35 \mathrm{~mm}$ yang tersebar di Sri Lanka, Queensland (Australia) hingga Indonesia (Gastropods 2021). OBIS (2021) menyatakan bahwa keong mangrove $C$. angulifera tergolong ke dalam Kingdom Animalia, Filum Moluska, Kelas Gastropoda, Subkelas Heterobranchia, Infrakelas Euthyneura, Subterkelas Tectipleura, Superordo Eupulmonata, Ordo Ellobiida, Superfamili Ellobioidea, Famili Ellobiidae, Subfamili Pythiinae dan Genus Cassidula. 
Kajian terhadap moluska di Indonesia bagian timur telah dilakukan oleh Heryanto \& Radjab (2014) dari Kai Maluku dan Heryanto (2018) dari P. Tanimbar, namun kajian terhadap keong mangrove $C$. angulifera masih sangat minim dan/atau masih sangat sedikit dilakukan, terutama di Indonesia dan Kabupaten Merauke Papua, dimana hingga saat ini masih hanya dilakukan oleh Ariyanto et al. (2018) di pantai Banggi Provinsi Jawa Tengah. Sementara Dharmawan (1996), Elviana \& Lantang (2016), Maturbongs \& Elviana (2016), Merly \& Elviana (2017), Mathius et al. (2018), serta Elviana \& Monika (2019) hanya menemukan keberadaan keong mangrove $C$. angulifera di dalam kajiannya. Berdasarkan hal tersebut, maka kajian keong mangrove $C$. angulifera di Pantai Payum Merauke Papua Indonesia sangat perlu dilakukan. Hal ini bertujuan sebagai data dasar dalam pengelolaan mangrove di Indonesia khususnya di Kabupaten Merauke yang ditinjau dari bioekologi keong mangrove C. angulifera, baik itu struktur populasi, karakteristik lingkungan maupun faktor penentu distribusi dan kepadatannya.

\section{BAHAN DAN CARA KERJA}

Kajian dilakukan pada bulan September 2020 di kawasan ekosistem mangrove pantai Payum Kabupaten Merauke Provinsi Papua dengan tiga (3) stasiun pengamatan (Tabel 1 dan Gambar 1). Stasiun 1 berada di hutan mangrove sekitar permukiman masyarakat, Stasiun 2 berada di hutan mangrove sekitar area penangkapan nelayan tradisional dan Stasiun 3 berada di hutan mangrove yang jarang sekali terdapat aktivitas manusia (antropogenik) di sekitarnya. Data keong mangrove $C$. angulifera serta kondisi hutan mangrove dikumpulkan dengan cara membuat transek garis dan plot yang ditarik dari titik acuan (tegakan mangrove terluar) dan tegak lurus garis pantai sampai ke daratan (Ernanto et al. 2010), dimana transek garis dibuat petak-petak contoh (plot) dengan ukuran $10 \times 10 \mathrm{~m}$ dan di dalam ukuran $10 \times 10$ $\mathrm{m}$ tersebut dibuat plot kecil (subplot) yang berukuran 1 x $1 \mathrm{~m}$ sebanyak 5 subplot. Tiap stasiun terdiri dari 3 plot dan tiap plot terdiri dari 5 subplot, sehingga jumlah subplot keseluruhannya adalah 45. Sementara untuk pengumpulan data parameter kualitas air (suhu, $\mathrm{DO}, \mathrm{pH}$, salinitas) dilakukan secara in situ dengan suhu dan DO menggunakan water quality meter Lamotte 5-0107-01, sedangkan pH menggunakan $\mathrm{pH}$ meter Lutron 208 dan salinitas menggunakan alat hand refractometer. Selanjutnya, data kepadatan keong mangrove $C$. angulifera dianalisis berdasarkan Odum (1971), Southwood (1978) serta Brower \& Zar (1984), sedangkan data pola penyebaran keong mangrove C. angulifera dianalisis menggunakan Indeks Morisita (I $\delta$ ) (Krebs 1972; Kusmana \& Istomo 1995; Jongitvimol et al. 2005) dengan kriteria I $\delta$ $=1$ (pola penyebarannya acak), I $\delta<1$ (pola penyebarannya seragam) serta $\mathrm{I} \delta>1$ (pola penyebarannya mengelompok), kemudian untuk menghitung kerapatan mangrove di pantai Payum Kabupaten Merauke Provinsi Papua digunakan metode penghitungan yang mengacu pada English et al. (1994) dan Bengen (2004), sedangkan untuk mengetahui penciri lingkungan dan faktor yang menentukan distribusi maupun

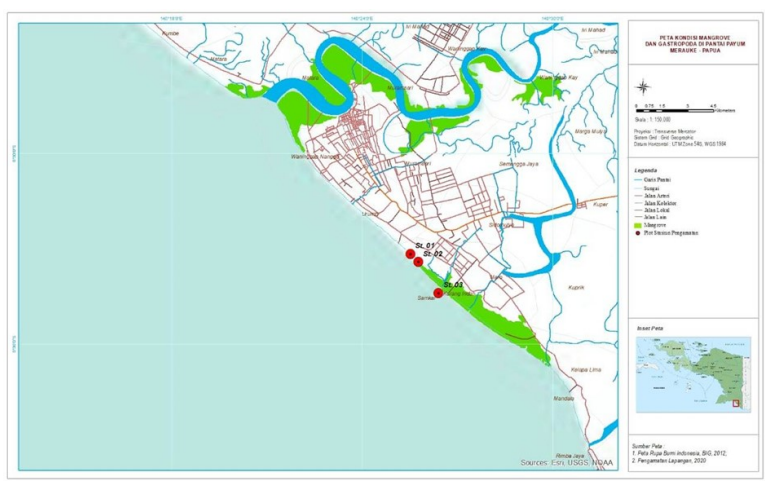

Gambar 1. Peta lokasi kajian

Tabel 1. Koordinat kajian karakteristik keong mangrove C. angulifera di pantai Payum Merauke Papua Indonesia.

\begin{tabular}{|c|c|c|c|}
\hline \multirow{2}{*}{ Lokasi } & \multirow{2}{*}{ St } & \multicolumn{2}{|c|}{ Koordinat } \\
\hline & & $\mathbf{S}$ & $\mathbf{E}$ \\
\hline Mangrove di sekitar permukiman masyarakat & 1 & $08^{\circ} 33^{\prime} 11.09 ’$ & $140^{\circ} 25^{\prime} 30.90^{\prime \prime}$ \\
\hline Mangrove di sekitar area penangkapan nelayan & 2 & $08^{\circ} 33^{\prime} 25.65^{\prime \prime}$ & $140^{\circ} 25^{\prime} 45.75^{\prime \prime}$ \\
\hline Mangrove tanpa aktivitas manusia di sekitarnya & 3 & $08^{\circ} 34^{\prime} 00.26^{\prime \prime}$ & $140^{\circ} 26^{\prime} 23.93^{\prime \prime}$ \\
\hline
\end{tabular}


kepadatan keong mangrove $C$. angulifera di kawasan mangrove pantai Payum Kabupaten Merauke Provinsi Papua dianalisis menggunakan statistik multivariat Principal Component Analysis (PCA) (Syahrial et al. 2019).

\section{HASIL}

\section{Struktur Populasi}

Kepadatan keong mangrove $C$. angulifera di kawasan mangrove pantai Payum Kabupaten Merauke Provinsi Papua bervariasi untuk setiap stasiun pengamatannya, dimana kepadatan tertinggi berada pada Stasiun $2\left(40,67 \mathrm{ind} / \mathrm{m}^{2}\right)$ dan terendahnya berada pada Stasiun 3 (5 ind/ $\mathrm{m}^{2}$ ) (Gambar 2), kemudian untuk pola penyebaran keong mangrove $C$. angulifera di kawasan mangrove pantai Payum Kabupaten Merauke Provinsi Papua, secara keseluruhannya tergolong seragam $(\mathrm{I} \delta<1)$ (Tabel 2).

\section{Karakteristik Lingkungan}

Hasil penghitungan kondisi kerapatan mangrove di pantai Payum Kabupaten Merauke Provinsi Papua memperlihatkan bahwa secara keseluruhan kerapatan mangrovenya tergolong tinggi ( $>1000 \mathrm{ind} / \mathrm{ha})$, dimana kerapatan tertingginya berada pada Stasiun $3(1566,67$ ind/ha) dan terendahnya berada pada Stasiun 1 (1400 ind/ha) (Gambar 3). Untuk pengukuran

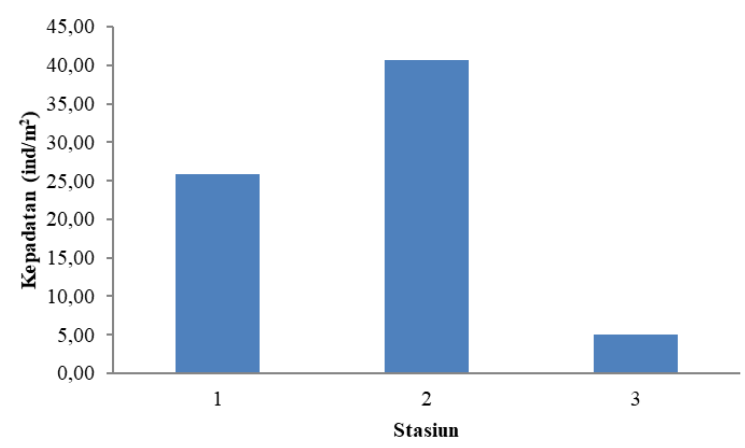

Gambar 2. Kepadatan keong mangrove $C$. angulifera di masing-masing stasiun pengamatan.

Tabel 2. Pola penyebaran keong mangrove $C$. angulifera di pantai Payum Merauke Papua Indonesia.

\begin{tabular}{lccc}
\hline & Stasiun 1 & Stasiun 2 & Stasiun 3 \\
\hline Indeks Morisita $(\mathrm{I} \delta$ ) & 0,01 & 0,00 & 0,17 \\
Pola Penyebaran & Seragam & Seragam & Seragam \\
\hline
\end{tabular}

kualitas perairan di pantai Payum Kabupaten Merauke Provinsi Papua memperlihatkan bahwa parameter suhu berkisar antara $28,33-31,67^{\circ} \mathrm{C}$, DO 5,60 - 7,67 mg/L, pH 6,83 - 7,53 dan salinitas 29,33 - 30,00\% (Tabel 3). Hasil analisis PCA untuk penciri lingkungan keong mangrove $C$. angulifera memperlihatkan bahwa adanya pembentukan 2 kelompok (Gambar 4) dengan kelompok pertama di Stasiun 3 dipengaruhi oleh salinitas, suhu, DO dan kerapatan mangrove yang tinggi, sedangkan kelompok kedua di Stasiun 1 dan 2 dipengaruhi oleh $\mathrm{pH}$ yang tinggi serta diameter batang mangrove yang besar.

\section{Faktor Penentu Distribusi dan Kepadatan Keong Mangrove $C$. angulifera}

Faktor penentu distribusi dan kepadatan keong mangrove $C$. angulifera di pantai Payum Kabupaten Merauke Provinsi Papua berdasarkan hasil analisis PCA terbagi atas tiga (3) kelompok. Untuk kelompok pertama terdiri dari suhu, DO dan kerapatan mangrove, kemudian kelompok kedua terdiri dari $\mathrm{pH}$ dan salinitas, sedangkan kelompok ketiga hanya terdiri dari diameter

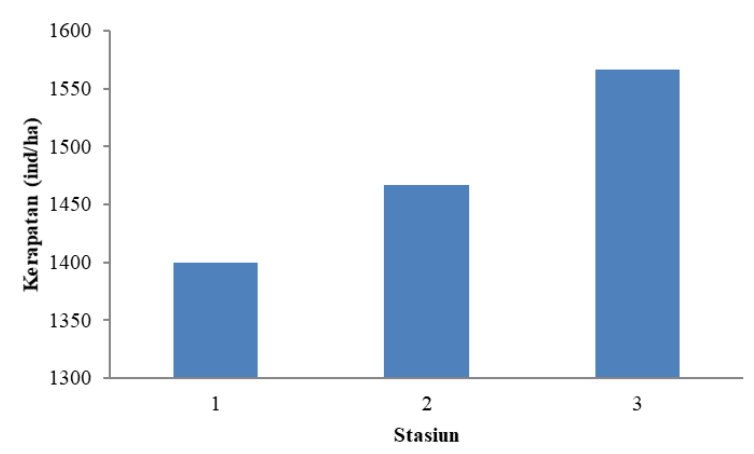

Gambar 3. Kerapatan mangrove di masing-masing stasiun pengamatan pantai Payum Kabupaten Merauke Provinsi Papua.

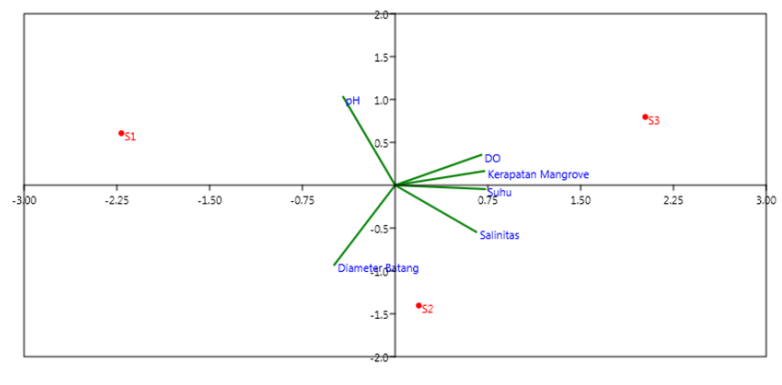

Gambar 4. Penciri lingkungan keong mangrove $C$. angulifera di ekosistem mangrove pantai Payum Merauke Papua 
batang, dimana nilai eigen untuk ketiga kelompok tersebut adalah lebih dari satu dengan total keragaman datanya sebesar 81,66\% (Tabel 4).

\section{PEMBAHASAN}

Informasi mengenai kepadatan suatu populasi dapat memberikan gambaran terhadap keadaan populasi tersebut di suatu habitat. Kepadatan keong mangrove $C$. angulifera di pantai Payum Kabupaten Merauke Provinsi Papua, hasilnya bervariasi (Gambar 2) yang diduga karena berbedanya kadar bahan organik yang terkandung pada masing-masing stasiun pengamatan dan diduga juga karena kondisi fisik perairan sekitarnya (seperti kekuatan gelombang/ombak yang menghantam daratan). Pada Stasiun 2, tegakan mangrove dominannya adalah Avicennia alba daripada $R$. stylosa, dimana $A$. alba merupakan spesies mangrove yang memiliki rumpun daun sangat lebat serta helaian daun yang tipis, sehingga daunnya lebih mudah jatuh dan mudah dihancurkan oleh bakteri pengurai dibandingkan $R$. stylosa, kemudian di Stasiun 2 juga memiliki kondisi gelombang/ombak yang tidak terlalu kuat, sehingga kandungan bahan organiknya tidak banyak terbawa ke laut, baik itu oleh arus ataupun air pasang surut. Sementara untuk
Stasiun 3, kerapatan mangrovenya lebih tinggi dan juga didominasi oleh tegakan $A$. alba dibandingkan $R$. stylosa maupun Ceriops tagal (menyebabkan kandungan bahan organiknya lebih tinggi). Akan tetapi, kondisi gelombang/ ombak laut di Stasiun 3 sangat kuat, sehingga menyebabkan kandungan bahan organiknya menjadi berkurang karena sudah terbawa ke laut oleh arus ataupun air pasang surut. Menurut Budiasih et al. (2015) bahan organik yang terdapat di dalam sedimen mangrove merupakan nutrien yang dibutuhkan oleh mangrove untuk kesuburannya, dimana serasah mangrove merupakan penyuplai bahan organik tersebut, sehingga mampu menunjang kehidupan makhluk hidup di dalamnya (Andrianto et al. 2015). Selain itu, fraksi sampah yang ada di atas tanah maupun akar-akar mangrove yang sudah mati, dimineralisasi oleh dekomposisi mikroba, kemudian sisanya distabilkan untuk bahan organik (Liu et al. 2017). Ariyanto et al. (2018) menyatakan bahwa keong mangrove $C$. angulifera yang berukuran besar sangat bergantung pada ketersediaan senyawa organik, hal ini merupakan sumber makanannya.

Pola penyebaran keong mangrove $C$. angulifera di kawasan mangrove pantai Payum Kabupaten Merauke, Papua mengindikasikan bahwa kondisi lingkungan ekosistem mangrovenya adalah sama atau merata (uniform), baik itu

Tabel 3. Kualitas perairan keong mangrove C. angulifera di masing-masing stasiun.

\begin{tabular}{ccccc}
\hline \multirow{2}{*}{ Stasiun } & \multicolumn{4}{c}{ Kualitas Perairan } \\
\cline { 2 - 5 } & Suhu $\left({ }^{\circ} \mathbf{C}\right)$ & DO $(\mathbf{m g} / \mathbf{L})$ & $\mathbf{p H}$ & Salintas (\%o) \\
\hline 1 & $28,33 \pm 1,53$ & $5,60 \pm 0,53$ & $7,53 \pm 0,41$ & $29,33 \pm 1,15$ \\
2 & $30,33 \pm 0,58$ & $6,26 \pm 0,33$ & $6,83 \pm 0,29$ & $30,00 \pm 0,00$ \\
3 & $31,67 \pm 2,89$ & $7,67 \pm 0,23$ & $7,17 \pm 0,76$ & $30,00 \pm 0,00$ \\
Baku Mutu MNLH (2004) & $\mathbf{2 8}-\mathbf{3 2}$ & $>\mathbf{5}$ & $\mathbf{7 - 8 , 5}$ & s/d 34 \\
\hline
\end{tabular}

Tabel 4. Hasil analisis PCA faktor penentu distribusi dan kepadatan keong mangrove C. angulifera di ekosistem mangrove pantai Payum Merauke Papua.

\begin{tabular}{|c|c|c|c|c|c|c|}
\hline \multirow{2}{*}{$\begin{array}{c}\text { Principal } \\
\text { Component } \\
\text { (PC) }\end{array}$} & \multicolumn{3}{|c|}{ Initial Eigenvalues } & \multirow[b]{2}{*}{$\begin{array}{c}\text { Nama } \\
\text { variabel }\end{array}$} & \multirow{2}{*}{$\begin{array}{c}\text { Faktor } \\
\text { Loading }\end{array}$} & \multirow{2}{*}{$\begin{array}{c}\text { Varian yang } \\
\text { Dijelaskan } \\
(\%)\end{array}$} \\
\hline & Total & $\begin{array}{c}\% \% \text { of } \\
\text { Variance } \\
\end{array}$ & $\begin{array}{c}\text { Cumulative } \\
\%\end{array}$ & & & \\
\hline 1 & 2,24 & 37,28 & 37,28 & $\begin{array}{l}\text { DO } \\
\text { Suhu } \\
\text { KRM }\end{array}$ & $\begin{array}{l}0,779 \\
0,722 \\
0,705\end{array}$ & 37,28 \\
\hline 2 & 1,56 & 25,94 & 63,22 & $\begin{array}{l}\mathrm{pH} \\
\text { Salinitas }\end{array}$ & $\begin{array}{c}-0,580 \\
0,555 \\
\end{array}$ & 25,94 \\
\hline 3 & 1,11 & 18,44 & 81,66 & DBT & 0,643 & 18,44 \\
\hline
\end{tabular}

Keterangan: $\mathrm{KRM}=$ Kerapatan mangrove; $\mathrm{DBT}=$ Diameter batang. 
faktor fisika, kimia maupun kandungan nutrisinya (Tabel 2), dimana pola penyebaran keong mangrove $C$. angulifera yang seragam di kawasan mangrove pantai Payum Kabupaten Merauke Provinsi Papua sama dengan pola penyebaran keong mangrove Littoraria scabra yang didapatkan oleh Syahrial \& Karsim (2018) di hutan mangrove Pulau Tunda Serang Banten. Scheibling (1980) menyatakan bahwa faktorfaktor yang dapat mengakibatkan sebaran suatu spesies tidak acak adalah karena respon individu terhadap berbagai keadaan lingkungannya, misalnya distribusi pakan, heterogenitas substrat serta ketertarikan intraspesifik yang menandai masa reproduksi suatu spesies, sehingga faktor-faktor tersebut akan saling berinteraksi dan menciptakan variasi temporal maupun spasial pada sebaran suatu spesies. Selain itu, seragamnya pola penyebaran suatu spesies juga dapat disebabkan oleh interaksi negatif antara individu-individu, seperti kompetisi terhadap ketersediaan makanan misalnya (Husein et al. 2017).

Untuk kondisi vegetasi melalui potensi kerapatan, mengambarkan adanya penguasaan terhadap sumber hara oleh jenis vegetasi mangrove, dimana vegetasi mangrove yang memiliki kerapatan tinggi berarti juga memiliki tingkat penguasaan hara yang besar/tinggi (Ray et al. 2014). Tingginya kerapatan mangrove di pantai Payum Kabupaten Merauke Provinsi Papua (Gambar 3) diduga karena aktivitas penebangan yang masih sangat rendah. Menurut UNEP (2014) terancamnya hutan mangrove di seluruh dunia disebabkan oleh dampak antropogenik manusia terhadap hutan mangrove, dimana potensi penambahan luasan mangrove dunia tidak dapat mengimbangi kehilangannya akibat dari antropogenik manusia yang terus menerus terjadi (Feller et al. 2017) dan tekanan yang umum dialami oleh ekosistem mangrove dari antropogenik manusia adalah konversi penggunaan lahan budidaya, pertanian dan pembangunan perkotaan (Friess \& Webb 2013). Selain itu, juga dapat disebabkan oleh aktivitas pelabuhan maupun industri (Zhang et al. 2014) serta peningkatan jumlah penduduk yang semakin tinggi (UNEP 2014; Pramudji \& Dharmawan 2016). Selanjutnya berdasarkan pengukuran di lapangan, kualitas perairan di pantai Payum Kabupaten Merauke Provinsi
Papua secara keseluruhannya tidak melebihi baku mutu yang telah ditetapkan dan tidak menyebabkan sebagai faktor pembatas bagi kelangsungan hidup keong mangrove $C$. angulifera maupun vegetasi mangrovenya (Tabel 3). Ali et al. (2013) dan Saintilan et al. (2014) menyatakan bahwa suhu merupakan salah satu faktor pembatas utama bagi tumbuhan mangrove, dimana suhu rata-rata dapat memberikan penjelasan secara korelatif terhadap distribusi mangrove di dunia. Selanjutnya, Hadiputra \& Damayanti (2013) menyatakan bahwa sumber utama DO di perairan merupakan hasil dari proses fotosintesis tumbuhan dan penyerapan/pengikatan secara langsung oksigen dari udara melalui kontak antara permukaan air dengan udara, kemudian tinggi rendahnya $\mathrm{pH}$ lingkungan sangat dipengaruhi oleh fluktuasi kandungan $\mathrm{O}_{2}$ maupun $\mathrm{CO}_{2}$ (Rukminasari et al. 2014) serta salinitas merupakan salah satu parameter lingkungan yang paling penting dalam mendorong struktur komunitas maupun komposisi spesies mangrove di suatu wilayah (Ball 2002).

Pengelompokkan-pengelompokkan karakteristik lingkungan sebagai penciri masingmasing ekologi stasiun pengamatan (Gambar 4) memperlihatkan adanya pengaruh dari kondisi perairan maupun aktivitas manusia di sekitar, dimana pada kelompok pertama (Stasiun 3) yang dicirikan oleh tingginya konsentrasi salinitas dan DO disebabkan karena tidak terdapatnya aliran air tawar (sungai/kanal) yang bermuara ke Stasiun 3 dan juga tidak terdapatnya aktivitas manusia (antropogenik) di sekitar lokasi pengamatan yang dapat menghasilkan limbah dan mencemari lingkungan, sedangkan tingginya kerapatan mangrove di Stasiun 3 disebabkan karena aktivitas pengrusakan mangrove oleh manusia masih sedikit. Sementara tingginya konsentrasi suhu di Stasiun 3 disebabkan karena pengukurannya dilakukan saat cahaya matahari bersinar terik, sehingga intensitas sinar matahari yang masuk ke badan perairan sangat tinggi dan menyebabkan suhu perairannya juga menjadi tinggi. Selanjutnya, pada kelompok kedua (Stasiun 1 dan 2) yang dicirikan oleh tingginya konsentrasi $\mathrm{pH}$ dan besarnya diameter batang mangrove disebabkan karena proses reduksi oksidasi dalam mengurai bahan organik 
lingkungannya masih sangat rendah/kecil, sehingga kandungan unsur hara di Stasiun 1 dan 2 masih tinggi dan menyebabkan diameter batang vegetasi mangrovenya lebih besar karena mendapatkan pasokan nutrisi yang sangat banyak. Di samping itu, berdasarkan nilai varian yang dimiliki oleh masing-masing kelompok hasil dari analisis PCA (Tabel 4) memperlihatkan kelompok pertama (suhu, DO dan kerapatan mangrove) merupakan kelompok yang paling mempengaruhi distribusi maupun kepadatan keong mangrove $C$. angulifera di pantai Payum Kabupaten Merauke Provinsi Papua. Hal ini karena kelompok pertama memiliki nilai varian yang lebih besar (37.28\%) bila dibandingkan dengan kelompok yang lainnya, sehingga mengindikasikan bahwa semakin tinggi konsentrasi suhu, DO maupun kerapatan mangrove, maka distribusi maupun kepadatan keong mangrove $C$. angulifera juga semakin tinggi dan begitu sebaliknya.

\section{KESIMPULAN}

Struktur populasi keong mangrove $C$. angulifera di kawasan mangrove pantai Payum Kabupaten Merauke Provinsi Papua untuk kepadatannya bervariasi di setiap stasiun pengamatan dengan pola penyebarannya tergolong seragam. Selanjutnya untuk karakteristik lingkungan, kerapatan mangrove sebagai habitat keong $C$. angulifera tergolong tinggi, parameter kualitas perairannya juga tidak melebihi baku mutu yang telah ditetapkan dan penciri lingkungannya membentuk 2 kelompok dengan kelompok pertamanya di Stasiun 3 dipengaruhi oleh salinitas, suhu, DO dan kerapatan mangrove yang tinggi, sedangkan kelompok kedua di Stasiun 1 dan 2 dipengaruhi oleh $\mathrm{pH}$ yang tinggi serta diameter batang mangrove yang besar. Sementara untuk faktor penentu distribusi dan kepadatan keong mangrove $C$. angulifera di kawasan mangrove pantai Payum Kabupaten Merauke Provinsi Papua terbagi atas tiga (3) kelompok dengan kelompok pertamanya terdiri dari suhu, DO dan kerapatan mangrove, kemudian kelompok kedua terdiri dari $\mathrm{pH}$ dan salinitas, sedangkan kelompok ketiganya hanya terdiri dari diameter batang.

\section{UCAPAN TERIMA KASIH}

Ucapan terima kasih disampaikan kepada Lembaga Penelitian dan Pengabdian Kepada Masyarakat (LP2M) Universitas Musamus yang telah memfasilitasi penulis dalam melakukan kajian ini melalui dana Daftar Isian Pelaksanaan Anggaran (DIPA) Internal Skim Penelitian Dosen Pemula tahun anggaran 2020, dengan nomor kontrak 177.6/UN52.8/LT/2020.

\section{DAFTAR PUSTAKA}

Adams, H., \& A. Adams. 1854. Contributions towards the natural history of the Auriculidae a family of Pulmoniferous mollusca; with descriptions of many new species from the Cumingian collection. Zoology 22(1): 30 - 37.

Ali, A., Soemarno, \& M. Purnomo. 2013. Kajian kualitas air dan status mutu air Sungai Metro Di Kecamatan Sukun Kota Malang. Bumi Lestari 13(2): 265 - 274.

Alongi DM. 2002. Present state and future of the world's mangrove forests. Environmental Conservation. 29(3): $331-349$.

Andrianto, F., A. Bintoro, \& SB. Yuwono. 2015. Produksi dan laju dekomposisi serasah mangrove (Rhizophora sp.) di Desa Durian dan Desa Batu Menyan Kecamatan Padang Cermin Kabupaten Pesawaran. Sylva Lestari. 3(1): 9- 20.

Ariyanto, D., DG. Bengen, T. Prartono, \& Y. Wardiatno. 2018. The association of Cassidula nucleus (Gmelin 1791) and Cassidula angulifera (Petit 1841) with mangrove in Banggi coast, Central Java, Indonesia. Aquaculture, Aquarium, Conservation and Legislation. 11(2): 348 361.

Ball, MC. 2002. Interactive effects of salinity and irradiance on growth: Implications for mangrove forest structure along salinity gradients. Trees 16(2-3): 126-139.

Barbier, EB., SD. Hacker, C. Kennedy, EW. Koch, AC. Stier, \& BR. Silliman. 2011. The value of estuarine and coastal ecosystem services. Ecological Monographs 81(2): $169-193$. 
Bengen, DG. 2004. Pedoman Teknis Pengenalan dan Pengelolaan Ekosistem Mangrove. IPB Press. Bogor.

Benzeev, R., N. Hutchinson, \& DA. Friess. 2017. Quantifying fisheries ecosystem services of mangroves and tropical artificial urban shorelines. Hydrobiologia. 803(1): 225 - 237.

Bremner, J. 2008. Species traits and ecological functioning in marine conservation and management. Experimental Marine Biology and Ecology. 366: 37 - 47.

Brower, JE., \& JH. Zar. 1984. Field and Laboratory Methods for General Ecology Second Edition. W.C. Brown Publishers.

Budiasih, R., Supriharyono, \& MR. Muskananfola. 2015. Analisis kandungan bahan organik, nitrat, fosfat pada sedimen di kawasan mangrove jenis Rhizophora dan Avicennia di Desa Timbulsloko, Demak. Management of Aquatic Resources. 4(3): 66-75.

Costanza, R., R. de Groot, P. Sutton, S. van der Ploeg, SJ. Anderson, I. Kubiszewski, S. Farber, \& RK. Turner. 2014. Changes in the global value of ecosystem services. Global Environmental Change. 26: 152 - 158.

Dharmawan, A. 1996. Pola komunitas dan kemelimpahan serta keanekaragaman moluska di hutan mangrove Laguna Segara Anak Taman Nasional Alas Purwo - Banyuwangi. Chimera. 1(2).

Duke, NC, JO. Meynecke, S. Dittmann, AM. Ellison, K. Anger, U. Berger, S. Cannicci, K. Diele, KC. Ewel, CD. Field, N. Koedam, SY. Lee, C. Marchand, \& I. Nordhaus. 2007. A world without mangroves?. Science. 317(5834): 41 - 42.

Eddy, S., A. Mulyana, MR. Ridho, \& I. Iskandar. 2015. Dampak aktivitas antropogenik terhadap degradasi hutan mangrove di Indonesia. Lingkungan dan Pembangunan. 1(3): $240-254$.

Elviana, S., \& B. Lantang. 2016. Inventarisasi gastropoda pada ekosistem mangrove di perairan pantai Payumb, Kabupaten Merauke. Agricola. 6(1): 40 - 45.

Elviana, S., \& NS. Monika. 2019. Kandungan fosfat dan nitrat kaitannya dengan keberadaan gastropoda pada ekosistem mangrove di perairan Kambapi, Kabupaten Merauke. Musamus Fisheries and Marine
Journal. 1(2): $74-83$.

English, S., C. Wilkinson, \& V. Baker. 1994. Survey Manual for Tropical Marine Resources. ASEAN-Australia Marine Science Project: Living Coastal Resources, Australian Institute of Marine Science. Townsvile, Australian.

Ernanto, R., F. Agustriani, \& R. Aryawati. 2010. Struktur komunitas gastropoda pada ekosistem mangrove di muara Sungai Batang Ogan Komering Ilir Sumatera Selatan. Maspari. 1: 73 - 78.

[FAO] Food And Agriculture Organization of The United Nations. 2007. Trees and Shrubs of the Maldives. Bangkok, Thailand.

Feagin, RA., N. Mukherjee, K. Shanker, AH. Baird, J. Cinner, AM. Kerr, N. Koedam, A. Sridhar, R. Arthur, LP. Jayatissa, DL. Seen, M. Menon, S. Rodriguez, M. Shamsuddoha, \& F. Dahdouh-Guebas. 2010. Shelter from the storm? Use and misuse of coastal vegetation bioshields for managing natural disasters. Conservation Letters. 3(1): $1-11$.

Feller, IC., DA. Friess, KW. Krauss, \& RR. Lewis III. 2017. The state of the world's mangroves in the $21^{\text {st }}$ century under climate change. Hydrobiologia. 803(1): 1 12.

Friess, DA., \& EL. Webb. 2013. Variability in mangrove change estimates and implications for the assessment of ecosystem service provision. Global Ecology and Biogeography 23(7): $715-725$.

Gastropods. 2021. Diakses dari http:// www.gastropods.com/.

Giri, C., B. Pengra, Z. Zhu, A. Singh, \& LL. Tieszen. 2007. Monitoring mangrove forest dynamics of the Sundarbans in Bangladesh and India using multi-temporal satellite data from 1973 to 2000. Estuarine, Coastal and Shelf Science. 73(1-2): $91-100$.

Goecke, SD., \& SM. Carstenn. 2017. Fish communities and juvenile habitat associated with non-native Rhizophora mangle L. in Hawai'i. Hydrobiologia. 803 (1): $209-224$.

Hadiputra, MA., \& A. Damayanti. 2013. Kajian potensi makrozoobentos sebagai bioindikator pencemaran logam berat tembaga $(\mathrm{Cu}) \mathrm{di}$ 
kawasan ekosistem mangrove Wonorejo Pantai Timur Surabaya. Prosiding Seminar Nasional Manajemen Teknologi XVIII. Surabaya, 27 Juli 2013. D-14-1 - D-14-8.

Hamilton, SE., \& D. Casey. 2016. Creation of a high spatio-temporal resolution global database of continuous mangrove forest cover for the $21^{\text {st }}$ century (CGMFC-21). Global Ecology and Biogeography.25(6): $729-738$.

Heryanto \& AW. Rajab. 2014. Dinamika Populasi Atactodea striata (Gmelin, 1791) (Mollusca: Mesodesmatidae) di Pantai Berpasir Ohoider, Kep. Kei Kecil, Maluku Tenggara. Jurnal biologi Indonesia. 10(1): $57-65$

Heryanto 2018. Benthic Molluscs Communities in the Intertidal Coast of Tanimbar Islands, West Southeast Mollucas. Jurnal biologi Indonesia. 14(1): 73-80.

Husein, S., Bahtiar, \& D. Oetama. 2017. Studi kepadatan dan distribusi Keong Bakau (Telescopium telescopium) di perairan mangrove Kecamatan Kaledupa Kabupaten Wakatobi. Manajemen Sumber Daya Perairan. 2(3):235 - 242.

Jongjitvimol, T., K. Boontawon, W. Wattanachaiyingcharoen, \& S. Deowanish. 2005. Nest dispersion of a stingless bee species, Trigona collina Smith, 1857 (Apidae, Meliponinae) in a mixed deciduous forest in Thailand. The Natural History Journal of Chulalongkorn University. 5(2): $69-71$.

Kelleway, JJ., N. Saintilan, PI. Macreadie, CG. Skilbeck, A. Zawadzki, \& PJ. Ralph. 2016. Seventy years of continuous encroachment substantially increases 'blue carbon' capacity as mangroves replace intertidal salt marshes. Global Change Biology. 22 (3): $1097-1109$.

Krauss, KW., KL. McKee, CE. Lovelock, DR. Cahoon, NSaintilan, R. Reef, \& L. Chen. 2014. How mangrove forests adjust to rising sea level. New Phytologist. 202(1): $19-34$.

Krebs, CJ. 1972. Ecology: The Experimental Analysis of Distribution and Abundance. New York: Harper \& Row.

Kusmana, C., \& Istomo. 1995. Ekologi Hutan.
Laboratorium Kehutanan Fakultas Kehutanan. Institut Pertanian Bogor. Bogor. Lasibani, SM., \& E. Kamal. 2010. Pola penyebaran pertumbuhan "propagul" mangrove Rhizophoraceae di kawasan pesisir Sumatera Barat. Mangrove dan Pesisir. 10(1): 33 - 38.

Lee, SY., JH. Primavera, F. Dahdouh-Guebas, K. McKee, JO. Bosire, S. Cannicci, K. Diele, F. Fromard, N. Koedam, C. Marchand, I. Mendelssohn, N. Mukherjee, \& S. Record. 2014. Ecological role and services of tropical mangrove ecosystems: A reassessment. Global Ecology and Biogeography. 23(7): $726-743$.

Liu, X., Y. Xiong, \& B. Liao. 2017. Relative contributions of leaf litter and fine roots to soil organic matter accumulation in mangrove forests. Plant and Soil. 421(12): $493-503$.

Martin, C., H. Almahasheer, \& CM. Duarte. 2019. Mangrove forests as traps for marine litter. Environmental Pollution. 247: $499-508$.

Mathius, RS., B. Lantang, \& MR. Maturbongs. 2018. Pengaruh faktor lingkungan terhadap keberadaan gastropoda pada ekosistem mangrove di Dermaga Lantamal Kelurahan Karang Indah Distrik Merauke Kabupaten Merauke. Musamus Fisheries and Marine Journal. 1(2): 33 48.

Maturbongs, MR., \& S. Elviana. 2016. Komposisi, kepadatan dan keanekaragaman jenis gastropoda di kawasan mangrove pesisir pantai Kambapi pada musim peralihan I. Ilmiah Agribisnis dan Perikanan. 9(2): 19 - 23.

Menendez, P., IJ. Losada, S. Torres-Ortega, S. Narayan, \& MW. Beck. 2020. The global flood protection benefits of mangroves. Scientific Reports. 10: 4404. doi: 10.1038/ s41598-020-61136-6.

Merly, SL, \& S. Elviana. 2017. Korelasi sebaran gastropoda dan bahan organik dasar pada ekosistem mangrove di perairan pantai Payum, Merauke. Agricola. 7(1): 56 - 67.

Murdiyarso, D., J. Purbopuspito, JB. Kauffman, MW. Warren, SD. Sasmito, DC. Donato, S. Manuri, H. Krisnawati, S. Taberima, \& 
S. Kurnianto. 2015. The potential of Indonesian mangrove forests for global climate change mitigation. Nature Climate Change. 5: 1089 - 1092.

[OBIS] Ocean Biodiversity Information System. 2021. Diakses dari https://obis.org.

Odum, EP. 1971. Fundamentals of Ecology $3^{\text {rd }}$ Edition. W. B. Saunders Co. Philadelphia.

Polidoro, BA., KE. Carpenter, L. Collins, NC. Duke, AM. Ellison, JC. Ellison, EJ. Farnsworth, ES. Fernando, K. Kathiresan, NE. Koedam, SR. Livingstone, T. Miyagi, GE. Moore, VN. Nam, JE. Ong, JH. Primavera, SG. Salmo, JC. Sanciangco, S. Sukardjo, Y. Wang, \& JW. Hong Yong. 2010. The loss of species: Mangrove extinction risk and geographic areas of global concern. Plos One. 5(4): DOI: 10.1371/journal.pone.0010095.

Pramudji, \& IWE. Dharmawan. 2016. Analisis pertumbuhan bibit bakau Rhizophora stylosa Griff. di kawasan rehabilitasi mangrove Tanjung Pasir, Tangerang. Oseanologi dan Limnologi di Indonesia. 1 (3): $91-100$.

Purnobasuki, H. 2011. Ancaman terhadap hutan mangrove di Indonesia dan langkah strategis pencegahannya. Bulletin PSL Universitas Surabaya. 25: $3-6$.

Ray, R., N. Majumder, S. Das, C. Chowdhury, \& TK. Jana. 2014. Biogeochemical cycle of nitrogen in a tropical mangrove ecosystem, East Coast of India. Marine Chemistry. 167: $33-43$.

Reid, DG., P. Dyal, \& S.T. Williams. 2010. Global diversification of mangrove fauna: A molecular phylogeny of Littoraria (Gastropoda: Littorinidae). Molecular Phylogenetics and Evolution. 55(1): 185 201.

Rukminasari, N., Nadiarti, \& K. Awaluddin. 2014. Pengaruh derajat keasaman $(\mathrm{pH})$ air laut terhadap konsentrasi kalsium dan laju pertumbuhan Halimeda sp. Torani. 24(1): $28-34$.

Saintilan, N., N. Wilson, K. Rogers, A. Rajkaran, \& KW. Krauss. 2014. Mangrove expansion and salt marsh decline at mangrove poleward limits. Global Change Biology. 20(1): $147-157$.
Schaduw, JNW. 2019. Struktur komunitas dan persentase penutupan kanopi mangrove Pulau Salawati Kabupaten Kepulauan Raja Ampat Provinsi Papua Barat. Majalah Geografi Indonesia 33(1): 26-34.

Scheibling, RE. 1980. Abundance, spatial distribution, and size structure of populations of Oreaster reticulatus (Echinodermata: Asteroidea) on sand bottoms. Marine Biology. 57(2): 107 - 119.

Southwood, TRE. 1978. Ecological Methods. London, Inggris.

Syahrial, \& N. Karsim. 2018. Distribusi spasial gastropoda Littoraria scabra di hutan mangrove Pulau Tunda, Serang, Banten. Marine Research and Technology. 1(1): 17 -21 .

Syahrial, N. Purwanti, HAMU. Sagala, N. Atikah, Y. Sari, B. Oktavian, \& N. Simbolon. 2019. Karakteristik Lingkungan dan Kondisi Fauna Makrobentik di Kawasan Reboisasi Mangrove Pulau Pramuka, Panggang, dan Karya, Kepulauan Seribu, Indonesia. Ilmiah Perikanan dan Kelautan. 11(1): $9-20$.

[UNEP] United Nations Environment Programme. 2014. The Importance of Mangroves to People: A Call to Action. van Bochove J, Sullivan E, Nakamura T. (Eds). United Nations Environment Programme World Conservation Monitoring Centre, Cambridge. 128 pp.

Wang, Y., J. Lee, JR. Werber, \& M. Elimelech. 2020. Capillary-driven desalination in a synthetic mangrove. Science Advances. 6 (eaax5253): 1 - 9 .

[WoRMS] World Register of Marine Species. 2021. Diakses dari http://www.marine species.org/.

Wu, J., Q. Xiao, J. Xu, M. Li, J. Pan, \& M. Yang. 2008. Natural products from true mangrove flora: Source, chemistry and bioactivities. Natural Product Reports. 25: 955 - 981.

Zhang, Z., X. Xu, Y. Sun, S. Yu, Y. Chen, \& J. Peng. 2014. Heavy metal and organic contaminants in mangrove ecosystems of China: A review. Environmental Science and Pollution Research. 21(20): 11938 11950. 